\title{
A brief essay on ergonomics in graphic design
}

\author{
André N. F. Mendonça ${ }^{\mathrm{a},{ }^{,},}$, Júlio C. S. van der Linden ${ }^{\mathrm{b}}$ and Tania M. G. Fonseca ${ }^{\mathrm{c}}$ \\ ${ }^{a}$ Universidade Federal do Rio Grande do Sul, UFRGS, Av. Paulo Gama, 110 - prédio 12105 - $3^{\circ}$ andar, sala \\ 332, Centro, 90040-060, Porto Alegre, RS, Brasil \\ ${ }^{\mathrm{b}}$ DEG, Departamento de Design e Expressão Gráfica, Universidade Federal do Rio Grande do Sul, UFRGS, Rua \\ Sarmento Leite, 320 / 504, Centro, 90050-170, Porto Alegre, RS, Brasil \\ c PGPSI, Programa de Pós-Graduação em Psicologia Social e Institucional, UFRGS, Rua Ramiro Barcelos, 2600 \\ - Sala 309, Santana, 90035-003, Porto Alegre, RS, Brasil
}

\begin{abstract}
Through Brazilian publication revision on the relations amongst Ergonomics and Design, we observed the tendency towards an approach focusing on product design. However, it is our duty to question which would be the influences of ergonomics in the graphic design. As a methodology, we considered the identification that the practices derived from ergonomics as epistemic system found in the main bibliography related to graphic design.
\end{abstract}

Keywords: editorial projects, warnings perception, corporate identity project, cognitive aspects

\section{Introduction}

The use of ergonomics principles in Graphic Design is common sense to academic researchers. Examples in literature lead to demonstrate the relevance of Ergonomics to professional practice of graphic designers (Gomes Filho, 2010) [7]. Considerations on human factors are applied in many fields of graphic design, as editorial design, warning signals project, visual identities, package design, amongst others. At what sense? When the human factors are applied in questions as usability, legibility and readability in an editorial project, or in warning signals, in relation to the attention given to the chromatic aspects, amongst others. On the other hand, it seems to be uncommon the association of the concept ergonomics in the researched bibliography, whether in those directed towards the study of ergonomics, or in those ones dedicated to the study of graphic design. However, despite of its relevance, issues about Ergonomics maybe are not present in Brazilian graphic design literature as it will be demonstrated by this work. In similar way, Brazilian publications on Ergonomics and
Design tend to focus on product design. What will be presented as innovation in this research it is a brief work to identify examples of application where a clear relationship amongst the Ergonomics and the graphic design.

In Brazilian graphic design books like: Planejamento Visual Gráfico [17], Como Criar Identidades Visuais Para Marcas de Sucesso [18], O livro e o designer II: Como criar e produzir livros [8], Geometria do Design [4], Design de advertência para embalagens [12], Guia de Artes Gráficas: Design e Layout [3], and O guia completo da cor [6], it will be found approaches in terms of reading ability, use of colors, editorial design, graphic design, brand design, harmonic balance in the space, gestalt laws, but no direct references in ergonomic epistemology. The same will happen with typographic books as Tipografia Digital: O impacto das novas tecnologias [5], Elementos do Estilo Tipográfico [2], Tipografia: Uma apresentação [16], amongst others, we'll find approaches with readability and legibility terms but, no references in ergonomic epistemology. On the other hand, in Brazilian books as Design Ergonomia Emoção, Ergonomia - Conceitos e Aplicações, and

*Corresponding author. E-mail: andrefurtadodesigner@gmail.com 
Ergonomia e Design, there are presented concepts concerning product design, but nothing, or close this, about graphic approach. Even a author as Bonsiepe, who made approaches product design and graphic design, the ergonomics is a term, maybe, so much more close to the product that the graphic [1].

In this context, the aim of this work is to contribute to apply ergonomics principles in graphics design teaching. The methodology used was to identify in the bibliography of graphic design, practices that are related to ergonomics as an epistemological system.

\section{Discussion}

\subsection{The ergonomics and warning signals - case study}

The design (graphic or product) and the ergonomics are knowledge that develop together, then, isn't probably that we have a good project without a ergonomics analysis in some level. As described by Niemeyer (2009) [16], is very important that the design of product or a graphic system consider that the constituent parts of the product as the language elements to the consumer through the use of shapes, colors, textures and materials. In the same way, Moraes (2002) [14], explains that in the process of communication, the message receiver (consumer) needs to receive it, that requires the following sequence of socio-psychological phenomena: attention, perception, understanding and memorization. So, the elements of informational ergonomics, or at least some these, are into the graphic design methodology.

Let's see the following question - Comparative analysis of eco-points: Brazil x Barcelona, Spain. First in Figure 1, eco-points usually found in Brazil:

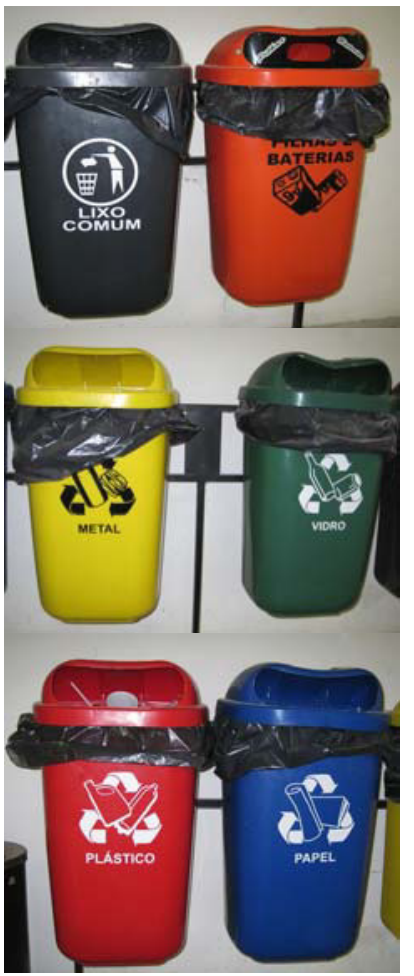

Figure 1. Eco-point in Rio de Janeiro

And now, in Figure 2 and in figure 3, the ecopoints usually found in Barcelona, Spain:

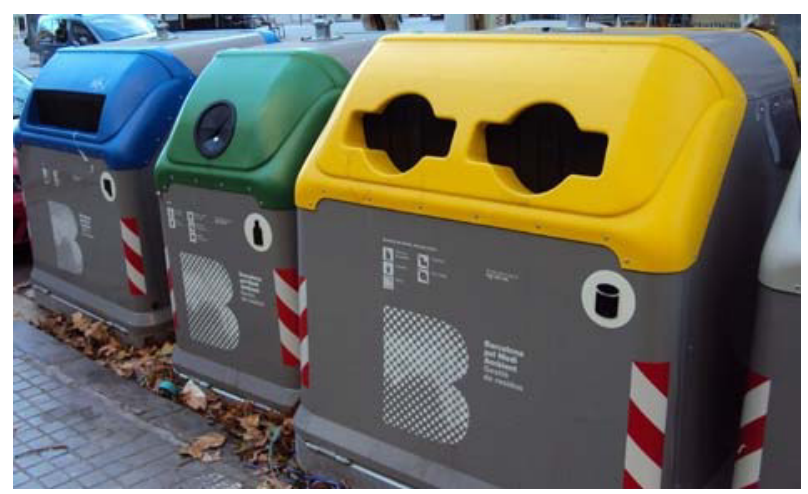

Figure 2. Eco-point in Barcelona 


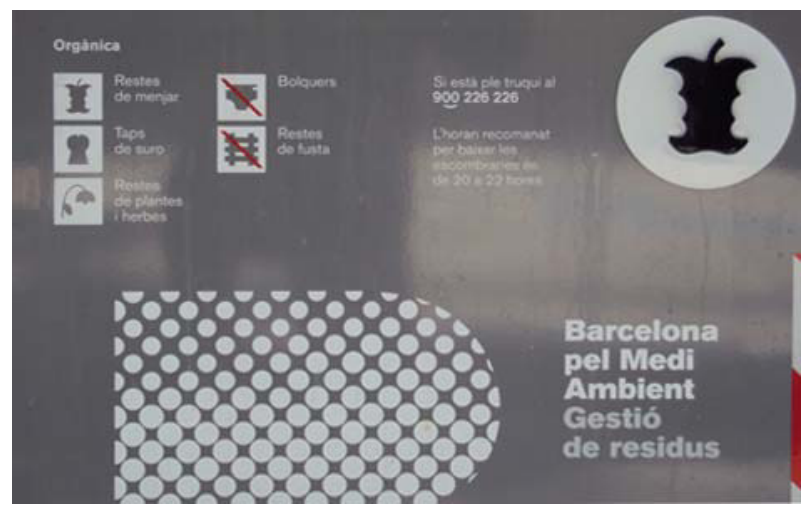

Figure 3. Eco-point in Barcelona, detail

Both projects present the following basic features in common:

- Specific colors for each type of wasting

- Each wasting box is meant for specific group of objects for discard.

- Each wasting box presents a redundant signaling system: color, legend and graphic signs.

How to distinguish them?

By means of layout study, the information organization, simplification of graphic signal lines, organization of space and elements. The legends were developed in such way to present clarity in the information layout with pictograms and easily understandable massages as pointed by Moraes (2002) [14]. Instead of having graphic elements with graphic surcharge, we can see isolated elements, easy identifiable, becoming very obvious what must be discarded in each garbage can.

\subsection{The ergonomics and the grid's application in the graphic project}

The organization of ideas in grids system is not property of present projects only, but it is something that can be identified in a very clear manner in the analysis of pictorial structure of hieroglyphs and in Greek and Roman tombstones and architectural projects, for example. We can observe this type of application in the paint project Transfiguration, by Raphael who, in 1520, applied a grid ${ }^{1}$ based on the aural section proportion as it can be demonstrated in the Figure 4 and in Figure 5. The historians such as Meggs and Purvis, and Ostrower, Doczi, Elam, and among others, describe this kind of application in

\footnotetext{
${ }^{1}$ This grid concept in Raphael paintings was discussed in before studies [11].
}

graphic design along the evolution of the use of the image.

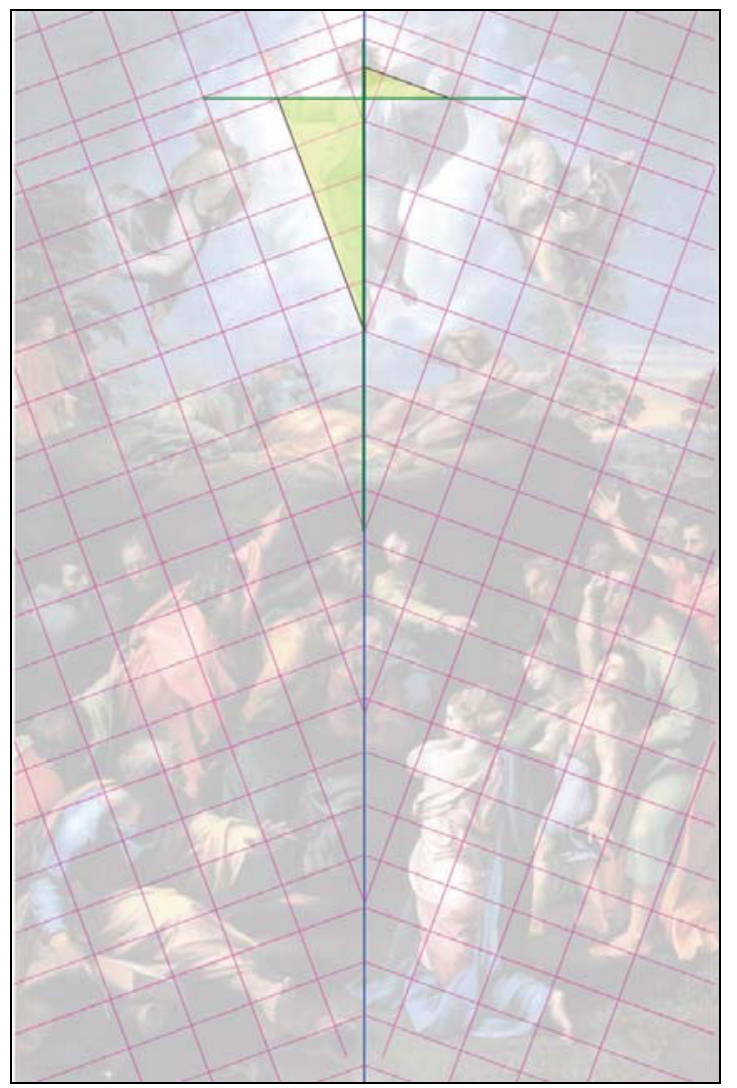

Figure 4. Application of aural section grid

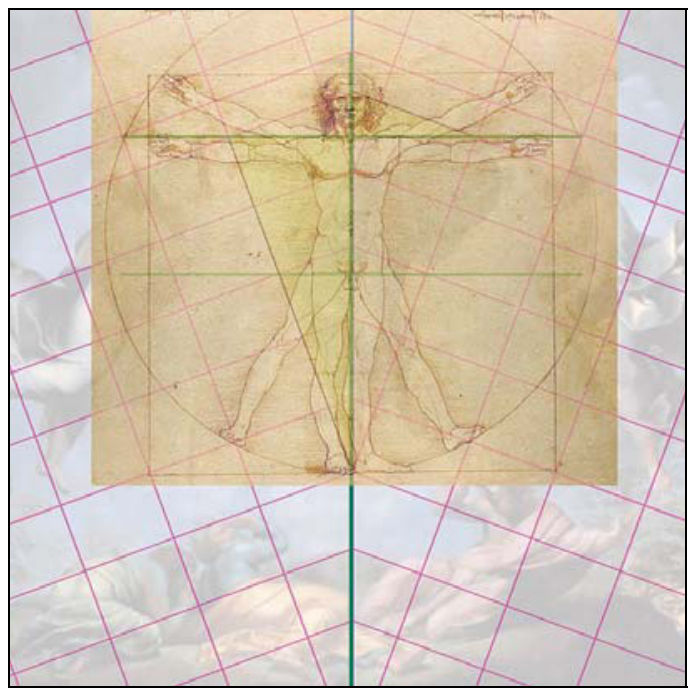

Figure 5. Diagram of the vitruvian man by Da Vinci overlying the Christ painted by Rafael, matching with the aural section grid 
As pointed by Meggs and Purvis (2009) [10], we find the use of the design principles as the organization of space, use of the gestalt and simplification of the shapes in the most of graphic designs. These design principles are very similar of those found in the ergonomics approaches ${ }^{2}$. In the Figure 6 and Figure 7, we can observe how the London underground map was made in 1908, before the grid layout application and after the Henry C. Beck intervention, around 1933.

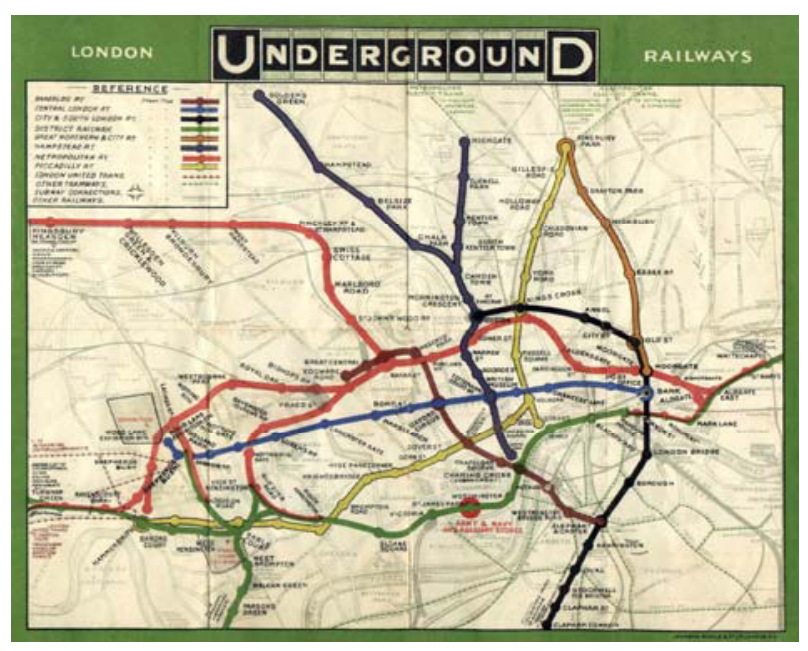

Figure 6. London underground map, 1908 [10]

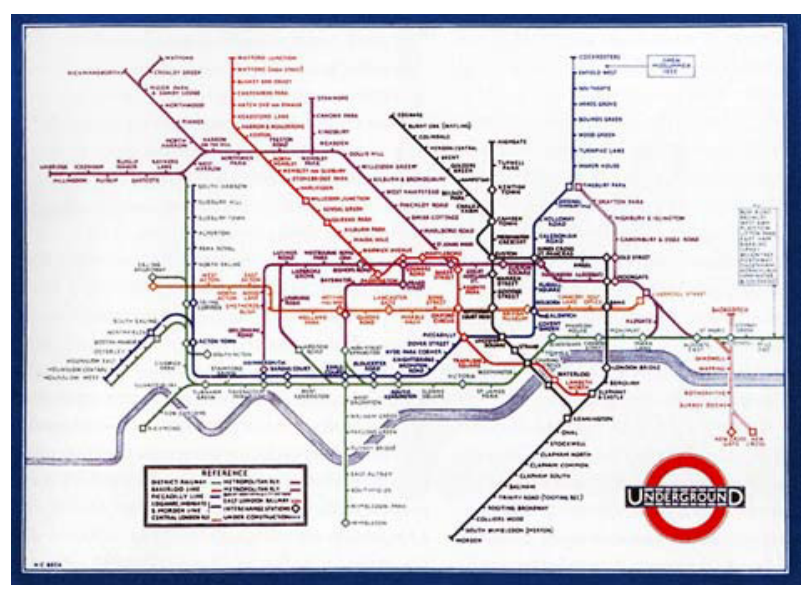

Figure 7. Henry C. Beck London underground map, 1933 [10]

\footnotetext{
${ }^{2}$ Consider the ergonomic approaches such as: interfacial, informational, cognitive, spatial, architectural, physical, environmental, organizational, urban, instructional among others $[9,13$, $15]$.
}

In Figure 8 and in Figure 9, Elam (2001) [4], show us other evidences in the applications of grids and of the organization of the space on editorial design.
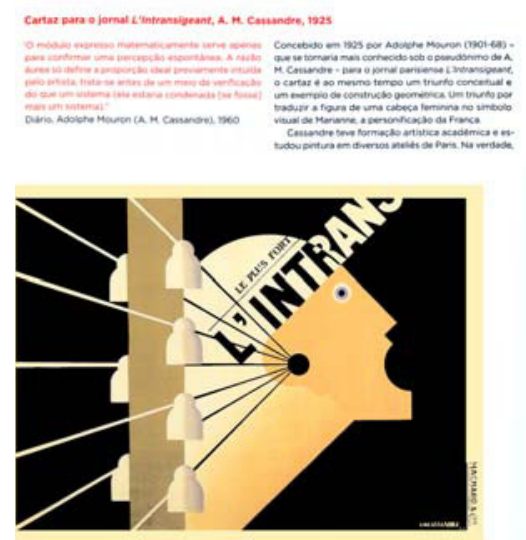

Figure 8. L'Intransigeant journal design by Mourion, 1925 [4]
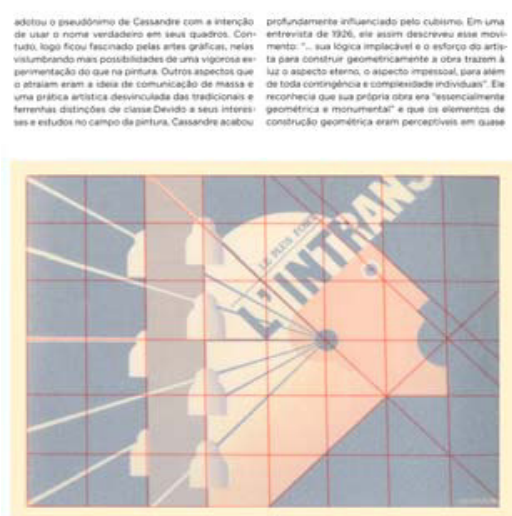

Figure 9. The grid application as showed by Elam [4]

\subsection{The ergonomics approaches and the project of marks}

In the Project of a particular mark, it is essential the attention focused on Ergonomics, by observing cognitive aspects in relation to the target public capacity in learning meanings from the image which is being visualized [18].

As pointed out by Niemeyer (2006) [16] and Moraes (2002) [14], the graphic designer must evaluate the consumer individual capacity in learning the meaning of an image and to consider the cultural factors which will favor the acceptance of the graphic signal or symbol by the collective. 
That's we can find, for example, in the family of symbols of Red Cross. See in the Figure, 10.

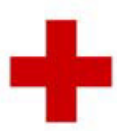

Red cross

occidental

countries
Red crescen

islamic

countries

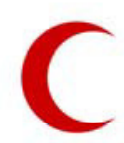

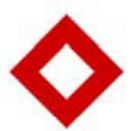

Red diamond proposal indicative out of Israel

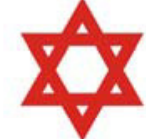

Red shield of David for indicative use within Israel
Figure 10. Cultural factors in ergonomics approaches

\subsection{Rebuilding a brand design}

When discussing the brand redesign, the graphic design will make use of features such as reducing the charge of visual elements, choice of the appropriated colors and typography, generation of a visual identity that fits to cultural factors, among others. In Figure 11 is possible to observe results of this process.
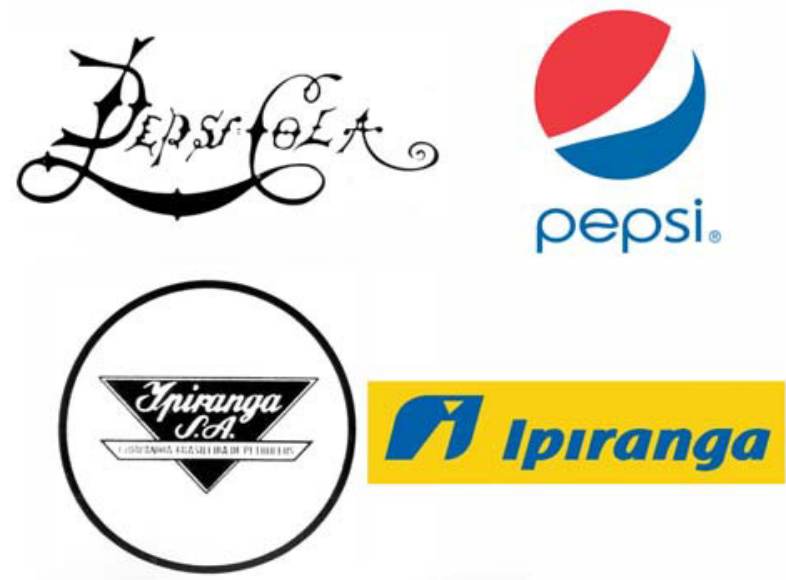

Figure 11. The Pepsi and Ipiranga brand redesign [18]

\subsection{The ergonomics and the editorial and typographic project}

In editorial projects, a very used resource is to define grids. The ergonomics in editorial project brings as two benefits $[16,19]$ :

- it is a comfort to somebody who reads it;

- it has the ability to drive the consumer's reading.

To provide this, the editorial design and typographic design will consider the legibility, the readability, the power of text relevance and the dynamic of layout as human factors in quality criteria.
Other feature in the editorial design is the grid application, considering the hot spots [17] and to guide the reader attention. See this in the Figure 12.

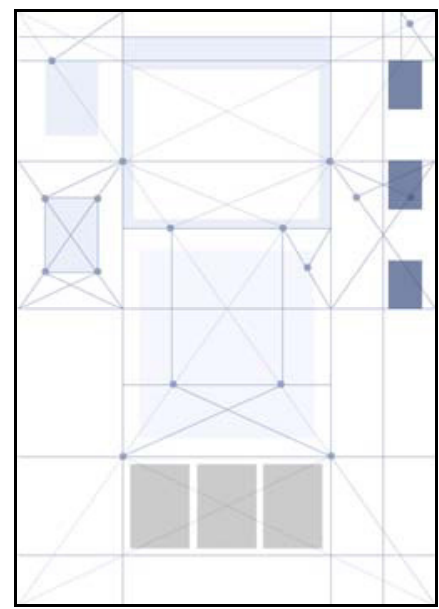

Figure 12. The grid with rot spots [16]

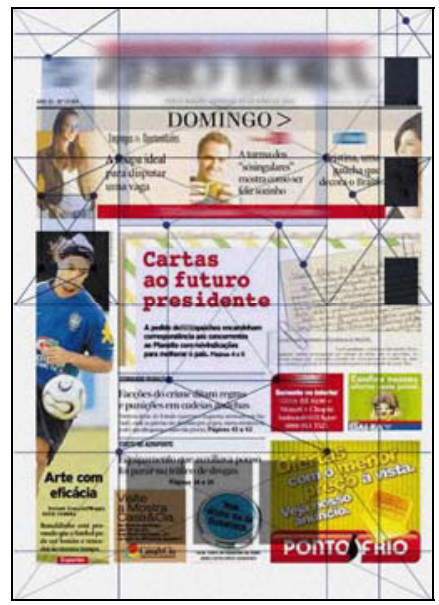

Figure 13. Application of the grid in editorial design

In the typographic design, to improve the legibility, the readability, the use of features as the tracking (or letter-spacing) and the kerning is usual, but the use of the serif typeface is also normally applied.

\section{Results}

The results find in this paper cover an extensive area of practices and theory on graphic design. Here there are presented four cases as examples:

- ergonomics applied in warning design, a case study; 
- ergonomics and the grid application in the graphic project;

- ergonomics and corporate identity project (brand design);

- ergonomics and editorial and typographic project.

The organization of ideas in a grid system is not only property of projects in current days, but it is something that can be identified in very clear way by the analysis of pictorial structure both in the write, books, paints, commercial pieces, as posters and cards, and so much more. It is clear, also in architectural, sculpture or in neolithic temples, for example. As showed, we can see this type of application in the painting Transfiguration, by Raphael who, in 1520, as it can be demonstrated in Figure 4. The goal was get the consumer attention, offering comfort and pleasure in the use these pieces of graphic design.

In corporate identity project, cognitive aspects in terms of public ability to get the message, the meaning of the image visualized, are similar as in ergonomics recommendations for warnings perception (Figure 2). As pointed out by Niemeyer (2006) [16] and Moraes (2002) [14], the graphic designer must evaluate the consumer individual ability and consider the cultural factors which will favor the acceptance of a graphic signal or symbol by the people you intend to achieve.

In editorial projects, a very used resource is to define grids. The ergonomics in editorial project brings benefits as the comfort of reading and the capacity of driving the consumer's reading.

\section{Conclusion}

The effectiveness of ergonomics recommendations to communication problems depends mainly on designers ability to create solutions that fit characteristics and requirements of users. The lack between ergonomics research and graphic design teaching needs to be reduced. To elaborate an appropriate literature basic that relate the Ergonomics and the Graphic de- sign is a relevant issue to training of designers and this work demonstrates that it is an opened challenge yet.

\section{References}

[1] Bonsiepe, G. (1997). Design do material ao digital. Florianópolis, SC: LBDI.

[2] Bringhurst, R. (2008). Elementos do Estilo Tipográfico. São Paulo, SP: Cosac Naify.

[3] Dabner, D. (2006). Guia de Artes Gráficas: Design e Layout. Barcelona: Editorial Gustavo Gili.

[4] Elam, K. (2010). Geometria do Design. São Paulo, SP: Cosac Naify.

[5] Farias, P. (2001).Tipografia Digital: O impacto das novas tecnologias. Rio de Janeiro, RJ: 2AB.

[6] Fraser, T. \& Banks, A. (2007). O guia completo da cor. São Paulo, SP: Editora SENAC.

[7] Gomes Filho, J. (2010). Ergonomia do Objeto - Sistema Tecnico De Leitura Ergonomica. São Paulo: Escrituras, 2010.

[8] Haslam, A. (2007). O livro e o designer II: Como criar e produzir livros. São Paulo, SP: Edições Rosari ltda.

[9] Linden, J. V. (2007). Ergonomia e Design. Porto Alegre, RS: Editora UniRitter.

[10]Meggs, P. B. e Purvis, A. W. (2009). História do Design Gráfico. São Paulo, SP: Cosac Naify.

[11] Mendonça, A. N. F. \& Fonseca, T. M. G. (2011). A arqueologia do projeto gráfico e os modos de subjetivação na arte de Rafael Sanzio. Revista Informática na Educação: teoria e prática, Porto Alegre, v.13, n.2, jul./dez. 2010.

[12]Mont'Alvão, C. (2002). Design de Advertência para embalagens. Rio de Janeiro, RJ: 2AB.

[13]Mont'Alvão, C. \& Damazio, V. (2008). Design Ergonomia Emoção. Rio de Janeiro, RJ: 2AB.

[14] Moraes, A. (2002). Ergonomia Informacional: a comunicação humano-tarefa-máquina; processamento, convergência e mudança de comportamento. In: Ergonomia Informacional Avisos, Advertências e Projeto Informacional. Rio de Janeiro, RJ: iUsEr, 2002.

[15] Moraes, A. \& Mont'Alvão, C. (2010). Ergonomia - Conceitos e Aplicações. Rio de Janeiro, RJ: 2AB.

[16] Niemeyer, L. (2006). Tipografia: Uma apresentação. Rio de Janeiro, RJ: 2AB.

[17] Ribeiro, M. (2007). Planejamento Visual Gráfico. Brasília: LGE Editora.

[18] Strunck, G. (2001). Como Criar Identidades Visuais Para Marcas de Sucesso. Rio de Janeiro, RJ: 2AB.

[19]Tondreau, B. (2009). Principios fundamentales de composición. Barcelona: Blum. 